\title{
TEACHERS' STRATEGIES IN TEACHING SPEAKING LESSONS ON INTROVERT STUDENTS IN MADRASAH ALIYAH (MA) JA-ALHAQ BENGKULU
}

\author{
M. Arif Rahman Hakim \\ School of Educational Studies, Universiti Sains Malaysia \\ 11800 Gelugor, Penang, Malaysia \\ E-mail: arifhakim9o@student.usm.my
}

\begin{abstract}
Abstrak: Strategi Guru Bahasa Inggris Dalam Mengajar Materi Speaking Terhadap Siswa Yang Berkarakteristik Introvert di Madrasah Aliyah (MA) Ja-alHaq Bengkulu. Kemampuan sesorang dalam berkomunikasi sering dipengaruhi oleh karakteristik kepribadiannya. Berdasarkan penelitian para ahli, terdapat dua karakter utama dalam diri seseorang, yaitu ekstrovert dan introvert. Siswa yang berkarakter introvert memiliki kemampuan yang tidak sama dengan siswa ektrovert dalam berkomunikasi bahasa asing. Untuk mengatasi problem tersebut, guru Madrasah Aliyah (MA) Ja-alHaq—sebagai objek penelitian ini-beberapa strategi agar kemampuan speaking siswasiswinya meningkat. Penelitian ini bertujuan untuk memberikan deskripsi dari guru bahasa Inggris di Indonesia yang berpengalaman dalam pengajaran speaking terkait dengan tantangan dan strategi dalam proses belajar mengajar bagi siswa yang berkarakteristik introvert. Berdasarkan hasil penelitian, dapat disimpulkan bahwa para guru disarankan untuk menerapkan diskusi, main peran, story telling, dan wawancara. Di samping itu, guru juga harus mengetahui karakter dari peserta didiknya karena dengan mengetahui kepribadian peserta didik, para guru dapat memilih strategi pembelajaran yang tepat untuk diterapkan di kelas.
\end{abstract}

Kata kunci: guru bahasa Inggris; pengajaran speaking; siswa introvert.

\begin{abstract}
Teachers' Strategies in Teaching Speaking Lessons on introvert Students in Madrasah Aliyah (MA) Ja-alHaq Bengkulu. The ability of a person in communication is often influenced by the characteristics of his personality. Based on the research of experts, there are two main characters in a person, namely extrovert and introvert. Students with an introverted character have a different ability than an orthograd student in communicating a foreign language. To overcome this problem, the teacher of Madrasah Aliyah (MA) Ja-alHaq-as the object of this study - did some strategies to improve students' speaking skills. This study aims to provide a description of English teachers in Indonesia who are experienced in speaking teaching related to the challenges and strategies in teaching and learning process for students with introverted characteristics. Based on the research results, it can be concluded that teachers are advised to apply the discussion, role play, story telling, and interview. In addition, the teacher must also know the character of the learners because by knowing the personality of learners, the teachers can choose the appropriate learning strategy to be applied in the classroom.
\end{abstract}

Keywords: English teacher; teaching speaking; introverted students.

\section{Introduction}

Mastering a foreign language is very important. Since the time of the Prophet Muhammad, the importance of understanding foreign languages has been emphasized. It is recorded in the hadith of Imam Ahmad, Abu Dawud and At-Turmuzi that Zaid bin Tsabit was commanded to learn the Hebrew language because the Prophet wanted to send a letter and in the end not less than half a month Zaid bin Tsabit had mastered the Jewish language. The Prophet's companion of the revelator recounted,
"After I had mastered it and the Prophet meant to send a letter to the Jews, so I wrote it for them, and if they sent a letter to the Prophet I would read them to him. "In another hadith, the Holy Prophet then sent Zaid bin Thabit to study the Syriac language. The hadith teaches that mastering a foreign language-moreover English is very important and even an urgent need for Muslims considering the need for foreign languages for various things in today's modern world.

In terms of English as a foreign language for 
Indonesian speakers, the dominance of English in general is undeniable. Until now, English is still used as a language of diplomacy, business, tourism, education, science, entertainment, computer technology, and media at the international level. In addition, English is used as a tool for developing communication, technology, programming, and software. Currently, the use of English appears in foreign countries such as Indonesia, and English is becoming more popular for people in this country.

In the context of developing the role of English in Indonesia, speaking seems to be a prime target for students even for everyone because of the issue of a free global market in ASEAN. That is why English becomes the main subject in the school curriculum in Indonesia. According to Thornbury, speaking is an important component of the English art curriculum and provides the basis for the growth of other spoken skills such as its close association with listening. 'In its relationship with speaking, foreign language introduction in the world of education-including English most widely used in schools/madrasah to universities in Indonesia-in the national curriculum as article 33 paragraph (3) of the National Education System Law of 2003 can be used. Therefore, speaking skills allow students to create connections between what they know and what they learn, and listening helps them to gain knowledge and explore new ideas.

There are two speaking models that can be delivered directly with good planning or grammatical meanings when we communicate orally with someone. The confidence and enthusiasm of students in speaking is the most important factor in developing their verbal skills or communication. However, in the context of learning English in foreign countries like in Indonesia, students tend to have problems with vocabulary, speaking, pronunciation and others. These factors sometimes make them lazy to learn English and they tend to rarely use English in their environment as in the classroom, neighborhood and at home.

1 S. Thornbury, How to Teach Speaking, (New York: Longman, 1989), p. 130
Brown stated that there are several factors that affect student speaking performance such as; anxiety, nervousness, and lack of selfconfidence. In addition, he also stated that the characteristics of students also affect their speaking performance. ${ }^{2}$ Next, Brown classifies the personality characteristics of a person into two types: extroverted and introverted. An extroverted person is a gregarious, "life of the party" person. ${ }^{3}$ Conversely, an introvert person is regarded as a calm and quiet person with a tendency toward a closed figure. In line with Brown, Friedman \& Schustack explain there are two main characters in a person. They are extroversion and introversion. These two terms are contradictory. They affect the competence of one's communication because of motivation and egoism between different extroversies and intrigues.

In short, personality and attitudes affect English learners as Foreign Language (EFL) in obtaining the target of language they are studying. Busch as quoted in Brown reported that those who are extroverts are less sensitive to stimuli than those who are introverts. ${ }^{4}$ Empirically, his studies show that an extroverted Japanese EFL student has better English pronunciation than those who are introverted, while those who are introverted tend to have higher achievements in reading and grammar.

In line with the empirical findings and related literature, the author's investigation shows that those who introvert feel embarrassed and talk less during classroom activities. Researchers observed a class dominated by introverted students. In line with reality, Rauch states that about a quarter of people in the world are introverts. He also explained that introverts always need to turn off (turn-off) and recharge (recharge) after making social contact with others. This is not anti-social, a sign of depression and it is not called meditation. ${ }^{5}$ For those who are introverted, being alone with their mind is as refreshing as sleeping and as nourishing as eating.

${ }^{2}$ H.D. Brown, Principles of Language Learning and Teaching ( $4^{\text {th }}$ ed.), (New York: Longman, 2000), p. 143

${ }^{3}$ H.D. Brown, Principles of Language..., p. 154

${ }^{4}$ H.D. Brown, Principles of Language..., p. 155

5 J. Rauch, Caring for Your Introvert, The Atlantic, (Februari 14 ${ }^{\text {th }}$ 2006), p. 24 
To obtain a deep study of introverted student behavior in learning English during class activities, this study then leads to Madrasah Aliyah (MA) Ja-alHaq students of Bengkulu city. This madrasah is interesting enough to be studied because the pesantren style that characterises the madrasah is "salafiyah", namely the yellow book based pesantren and using the salaf method in its learning, in the form of bandongan, sorogan and wetonan methods, but seriously applying foreign languages (Arabic and English ) as the language of "sunna" in everyday conversation. MA Ja-alHaq's students are encouraged to speak Arabic and English even though some of their students' inputs are "low". They are suggested to use foreign language. Although it is not applied daily in the madrasah, it make the students always try to talk.

The introverted behavior of MA Ja-alHaq's students in speaking English is very easy to find. Speaking in English is a serious obstacle when spoken. Students are confused of arranging words correct grammar and of the choice of which words should be spoken. Such obstacles can sometimes be overcome by students who really love to speak even when speech is wrong. However, for introverted students, such obstacles become more intense when fear of making mistake and inconfidence dominate their feelings. For this reason, teachers work with various strategies to make students always active and brave to speak a foreign language, which is English as the focus of the study in this article.

\section{Results and Discussion}

MA Ja-alHaq in the pesantren environment applies general learning and kepesantrenan. General learning implements the national curriculum while kepesantrenan applies the study of salafiyah yellow book. To support the acquisition of foreign languages (Arabic and English), a Foreign Language Development Organization (LPBA) was established, whose main task was to guide and direct its students to actively speak Arabic and English. On a regular basis, the LPBA supervises and guides students to practice Arabic and English conversation everyday.

In terms of mastery of the English language, MA Ja-alHaq stressed speaking English to all students gradually. That is, all students are not required to speak English which if there is any violation will not be subject to sanctions. They are only emphasized in English at best without any sanction for those who violate it; If you find that there are students who speak Indonesian or regional languages, they are only reprimanded. However, the English-speaking environment in this madrasah is alive and active despite the many obstacles found everywhere. And, the most dominant constraint is the discovery of introverted students.

Teachers and mentors at this madrasah realize that courage without fear of wrong is the key to successful speaking skills. In speaking, the important thing is to be courageous although many errors are found here and there. If we can make the listener understand what we mean, the conclusion is that we can communicate well. In this case, Harmer states that speaking skills are productive skills activities. ${ }^{6}$ This is the way in which the language is manifested in the communication function. This means that students have to talk a lot and teachers provide opportunities for students to communicate with each other as much as possible so that they can be active in learning and creative in developing ideas in speaking. In this case, the teacher should motivate the students in order to enlarge their imagination to speak.

MA teachers of Ja-alHaq who are teachers and tutors of English always encourage students to speak boldly in real communication. To enable students to communicate, conditioning in real situations as expressed by Bilbrough is always applied. ${ }^{7}$ This is because speaking is a speaker's speech that aims to express certain intentions so that the communication opponent (the

${ }^{6} \mathrm{~J}$. Harmer, How to Teach English: An introduction to the Practice of English Language Teaching, (New York: Logman, 1998), p. 88

7 N. Bilbrough, Dialogue Activities to Exploring Spoken Interaction in the Language Class, (Cambridge: Cambridge University Press, 2007), p. 107 
recipient of communication) is able to process and recognize the meaning of the message conveyed. Brown and Yule state that the delivery of the message depends on the complexity of the information to be communicated, however, the speakers sometimes find it difficult to clarify what they want to say. ${ }^{8}$ Related to the problem, Hughes states that "Speaking is the first way in which children acquire language, which is part of most people's engagement with daily linguistic activity, and is the main engine of language change. ${ }^{9}$ It also provides our primary data for understanding bilingualism and contact languages.

Theoretically, speaking is a way of expressing the mind. Collie \& Stephen states that "Speaking is referred to as an oral communication or expression of thoughts, ideas, and feelings in the form of words. ${ }^{10}$ In the teaching-learning process, in general, most MA Ja-alHaq students find some problems because English is indeed a foreign language. According to Brown, speaking is a demonstration of the ability to achieve pragmatic goals through interactive discourse with other speakers in the same language. ${ }^{11}$ Speaking as one form of communication means a language to interact with people verbally. In speaking, people are expected to communicate their ideas, feelings, and opinions. The goal is to create a comfortable social interaction and a good communication among participants. In line with the statement, Revola stated that students are reluctant to speak English because of the lack of vocabularies and phrases to express their ideas in English. ${ }^{2}$

Based on observations in madrasah, researchers classify some of the factors felt by learners as they study or when they apply

8 H.D. Brown and George Yule, Teaching the spoken Language. (Cambridge: Cambridge University Press, 1999), p. 14

${ }^{9}$ R. Hughes, Spoken English, TESOL, and Aplied Linguistics, (New York: Palgrave Macmillan, 2006), p. 144

${ }_{10} \mathrm{~J}$. Collie and S. Stephen, Speaking Student's Book, (Cambridge: Cambridge University Press, 2006), p. 15

1 H.D. Brown, Teaching by Principles: An Interactive Approach to Language Pedagogy, (New York: Logman, 2001), p. 267

${ }_{12}$ Y. Revola, An Analysis of Students' Problem in Public Speaking, (Thesis English Department of Tarbiyah Faculty, IAIN Bengkulu, 2012), p. 13
English speaking. Some of the factors that become obstacles in speaking among MA JaalHaq students are (1) anxious, (2) nervous, (3) not confident.

The first factor is anxiety. The students of MA Ja-alHaq are anxious for fear of expressing English vocabularies. Such anxiety is in average experienced by students because English is a "weird" language that is difficult to master. This anxiety has been alluded to by Harmer saying that students will exhibit extraordinary anxiety when they are asked to use a new language in activities such as oral reports, plays, roles, plays, or speaking and listening exams. ${ }^{13}$ Speaking in front of others is the most common cause of anxiety. Furthermore, he also stated that it is important to build friendship and relaxed classroom atmosphere, so as to help students to think that the classroom is a laboratory where they can experiment to take risks from a language.

Anxiety in speaking arises for several reasons. Some students are afraid of making mistakes. There is even a proverb "You are what you are talking about", therefore, students are reluctant to be judged by fellow students. This is the same as what Tillit and Brother say students are often stuck in trying to say about a thing in a foreign language in the classroom. ${ }^{14}$ One of the causes of concerns about making mistakes is that students are often reluctant to participate in speaking activities, as most of them are self-conscious and do not want to make mistakes or look stupid in front of their friends. The students are really afraid of failure, laughter, and mockery.

The second factor is nervous. Although some MA students of Ja-alHaq know the vocabulary and grammar, sometimes they still have a sense of nervousness. This condition may come from other students who speak English more fluently. Students who speak fluently will look more dominant in the class so that other students are reluctant to speak English. They choose to

${ }^{13}$ J. Harmer, The Practice of English Language Teaching, (Essex: Longman Limited, 2001), p. 87

14 B. Tillit and M. N. Bruder, Speaking Naturally, (Cambridge: Cambridge University Press, 1999), p. 20 
be quiet because they will be nervous if they speak English even though they have a vast supply of vocabulary.

The third obstacle is not confidence. Some of the MA students of Ja-alHaq are not confident when they will speak English. These feelings are sometimes based on their ability to speak English. Students with this trait think that their English is not as good as the others. They feel the other students can speak English better than them. They worry when they speak English, their friends will belittle them. Confidence consists of the perception of self-confidence in learning a second language and the lack of anxiety about learning or the use of the language itself.

In line with the phenomenon, Brown states that there are several factors that affect students' speaking performance such as anxiety, nervousness, and lack of confidence. ${ }^{15}$ In addition, he also stated that the characteristics of students also affect their speaking performance. Next, Brown classifies the personality characteristics of a person into two types: extroverted and introverted. The ones who are extrovert are those who like to make friends, and have "life of the party". Conversely, an introvert person is regarded as a calm and quiet person with a tendency toward a closed figure. Furthermore, Brown adds that extroversion is the extent to which one has a deep need to accept the ego's charm, selfesteem, and a sense of wholeness from others as opposed to receiving that affirmation within oneself. Those who are extroverts really need others to feel "good". But they are not always keen and talkative. They may be relatively shy but still need assertion from others. Introversy, on the other hand, is the extent to which one builds a sense of wholeness and fulfillment apart from this self-reflection from others. Contrary to our stereotype, those who are introvert can have inner strength as characters that are not possessed by those extroverts.

15 H.D. Brown, Principles of Language Learning and Teaching ( $4^{\text {th }}$ ed.), (New York: Longman, 2000), p.143

\section{Teachers' Strategy in Teaching Introverted Students}

Teachers are important components that influence student development. Leo mentions that a paid teacher is a professional educator, educated, showing high performance, and scientist whose primary job is to transform, develop and disseminate science, technology, and the arts through education, research and community service. ${ }^{16}$ The idea has actually been stated by the first Minister of Education of Indonesia, Ki Hajar Dewantara who shows three important characteristics of professional teachers. Characteristics selected are (a) Ing ngarso sung tuladha (in front, teacher becomes model), (b) Ing madya mangun karsa (in the middle, the teacher is the motivator), and (c) tut wuri handayani (behind, the teacher is a supporters).

The attitude of teachers is very important because it will affect the development of the students' minds and talents. In this case, Leo argues that attitude is a very important characteristic for a teacher. A positive attitude is a great asset to deal with all life's problems in the best possible way. The problem is not only as a teaching profession etiquette, but it has a high spirit and easy to remember to be delivered to our students.

A teacher's professional attitude is often invisible but certainly felt by the students. Harmer states that good teachers prepare everything well. ${ }^{17}$ He prepares lessons and teaching materials beforehand. He follows the usual grooves and is ready to organize scheduled activities. $\mathrm{He}$ is also ready for lessons that do not go as planned. He has a backup plan and is willing to change his plans if necessary.

Some of the common problems that can be described from the results of this study are as follows. First, the main problem faced by teachers is related to instructional instruction that includes material and syllabus. Teaching

${ }^{16}$ S. Leo, A Challenging Book to Practice Teaching in English, (Yogyakarta: Penerbit Andi, 2013), p. 239

$17 \mathrm{~J}$. Harmer, How to Teach English: An Introduction to the Practice of English Language Teaching, (New York: Logman, 1998) p. 242 
materials based on a scientific approach to facilitate students to be more active need to be well designed. The second problem is the motivation of students in speaking very low, and as a solution, the teacher gives them as many opportunities as possible to speak. Teachers should be as fair as possible so that each student has the opportunity to speak during the meeting.

With regard to observations, researchers found some information in the interaction of teaching and learning even though the class was very silent unlike other classes. When teachers enter and start classes, students seem to interact with their teachers and friends. Then, when the teacher gives a topic, they do not respond. Seeing the problem, the teacher offers some topics to the students and all those topics are related to real life. So, the teacher brings reality into the classroom. Then, the teacher devides the students into groups.

Associated with the activities in the speaking class, introverted students really feel comfortable if the teacher provides more opportunities for interaction between students, because in fact they really need it and it will be important for introverted students to upgrade their speaking skills. But the main problem is that they are less interacting in the learning process. Thus, the material being taught should contain more activities to improve student interaction. On the other hand, the introverted students actually prefer activities rather than theories in the course of speaking. Therefore, teaching materials must also represent the competence of cooperative learning as suggested by the teacher. During the research, several strategies of MA Ja-alHaq Bengkulu teachers in teaching and improving students' speaking were described as follows.

\section{Improving Student Discussion}

MA teacher Ja-alHaq diligently implements discussions of specific topics in English. With this strategy, the quiet students are slowly brave to speak even though the students are still stuttering in arranging the correct sentences. Latipah, a chemistry teacher who is proficient in English, is very aggressive and always invites students to discuss in English. The students are always invited to discuss to a conclusion. Sharing an idea about an event or finding a solution in a discussion group is always applied. In this way, students do not spend time chatting with each other about irrelevant things. However, students can actually be involved in agreeing or disagreeing in opinion. In this type of discussion, the Chemistry teacher forms groups of 4 or 5 students in each group. Then each group works on each topic for a certain period of time, and presents the results of their discussion in front of the class. As a result, students who had been embarrassed to speak, then began to speak courageously with their English skills.

\section{Forming Role Play}

Another way to improve students' speaking skills is by playing roles. Students pretend that they are in various social contexts and have various social roles. In this role-play activity, the teacher who always applies it is Bustomi (LPBA board) and Lisa Handayani, English teachers. Role-play activities are usually applied primarily in haflah events (third-class farewell events). In addition, when the "Gebyar Bahasa" is held once a year, students are trained to create their own English-language drama with very simple themes such as daily learning activities or misbehaving student stories at school. In the face of Gebyar Bahasa event, each class must usually form three groups of drama or English role play to be contested. This role playing activity turns out to be of great interest to the students because, as Harmer points out, they find the elements of art and entertaining acting.

\section{Creating Story Telling (Storytelling)}

In this activity, students are given a task and are trained to summarize stories or stories they hear from previous people verbally with English. Perhaps, they also make their own stories to tell their classmates. Story telling cultivates creative thinking. It also helps students express ideas in their initial form, 
development, and outcomes, including the characters and setting a story should have. Students can also tell puzzles or jokes. In this activity, the teacher who always teaches story telling is Lisa Handayani. At the beginning of each class session, the teacher may ask some students to tell a short riddle or joke as an opening. In this way, the teacher will not only improve the students' language skills, but also get the attention of the class.

\section{Training Interview}

Students can do interview on selected topics with different people. Exercise as the interviewer is usually assigned to students in groups. In each group, some are assigned as cameramen and interviewers. With its English proficiency, the students of MA Ja-alHaq interviewed several speakers around the boarding school of Ja-alHaq who are able to speak English such as (a) Abdul Halim, foundation administrator who is a lecturer at UNIB and alumni of Oxford University London, b) Bustomi, an LPBA administrator who is an IAIN lecturer in Bengkulu who has an English course in Pare Kediri, (c) Abdul Chalim, foundation manager who is an alumnus of Singapore; and (d) Latipah, a graduate of Chemistry graduate of UNIB and has ever been an English student in Pare Kediri. It is a good idea that teachers give rubrics to students so they know what type of questions will be delivered. Students should prepare their own interview questions. This strategy is done by the teacher and affects the students so that this activity provides an opportunity to practice speaking.

\section{Conclusion}

Based on the evidence from interviews and observations, there are three main problems faced by English teachers, especially in speaking subjects. They are classroom learning materials, student interaction with others, and opportunities for students. However, the main problem is the discovery of students who are quiet in speaking English even though the school environment is conditioned to always speak English. To solve these silent students, MA Ja-alHaq teachers perform various strategies. Some strategies used by MA Ja-alHaq Kota bengkulu teachers to improve students' speaking skill are (1) to improve discussion, (2) to form role play, (3) make story telling, and (4) train interview. These four strategies were able to significantly improve students' introverted speaking abilities. In the end, they dare to speak although there still make errors of structure everywhere.

\section{References}

Bilbrough, N, Dialogue Activities to Exploring Spoken Interaction in the Language Class, Cambridge: Cambridge University Press, 2010.

Brown, H.D., Gillian and Yule, George, Teaching the spoken Language, Cambridge University Press,1999.

Brown, H.D, Principles of Language Learning and Teaching (4 $4^{\text {th }}$ Edition), New York: Longman br, 2000.

, Teaching by Principles: An Interactive approach to Language Pedagogy, New York: Logman, 2001.

Borg, W.R, Applying Educational Research, New York: Longman, 1981.

Collie, J \& Stephen.S, Speaking Student's Book, Cambridge: Cambridge University Press, 2006.

Friedman, H.S. \& Miriam, W.S, Personality: Classic Theories and Modern Research ( $5^{\text {th }}$ ed), London: Pearson, 2011.

Harmer, J, How to Teach English: an introduction to the practice of English language teaching, New York: Longman, 1998.

, The Practice of English Language Teaching, Essex: Longman Limited, 2001.

Hughes, R, Spoken English, TESOL, and Aplied Linguistics, New York: Palgrave Macmillan, 2006.

Leo, S, A Challenging Book to Practice Teaching in English, Yogyakarta: Penerbit Andi, 2013.

Mustofa, M,The Journey of Professional Teachers, Language- Edu: Journal of English Teaching and Learning, 1 (1): 1-9, 2012.

Olson, M. H. \& B.R, Horgenhahn, Teori-teori Kepribadian, terjemahan oleh Yudi Santoro. Yogyakarta: Pustaka Pelajar, 2011.

Rauch,J, 14 Februari. Caring for Your Introvert, Februari $14^{\text {th }} 2006$. 
Revola,Y. An Analysis of Students' Problem in Speaking Unpublished thesis. Bengkulu: Fakultas Tarbiyah IAIN Bengkulu, 2012.

Thornbury, S, How to Teach Speaking. New York: Logman, 1989.
Thornbury, S and Slade, D., Conversation: From Description to Pedagogy. Cambridge: Cambridge University Press, 2006.

Tillit, B., \& Bruder, M.N, Speaking Naturally, Cambridge: Cambridge University Press, 1999. 